European Journal of Turkish Studies

Social Sciences on Contemporary Turkey

$27 \mid 2018$

Religion as a Foreign Policy Tool

\title{
Transformation of the Turkish Diyanet both at Home and Abroad: Three Stages
}

Ahmet Erdi Öztürk

\section{(2) OpenEdition \\ Journals}

Electronic version

URL: http://journals.openedition.org/ejts/5944

DOI: $10.4000 /$ ejts.5944

ISSN: $1773-0546$

Publisher

EJTS

Electronic reference

Ahmet Erdi Öztürk, «Transformation of the Turkish Diyanet both at Home and Abroad: Three Stages », European Journal of Turkish Studies [Online], 27 | 2018, Online since 17 January 2019, connection on 16 February 2020. URL : http://journals.openedition.org/ejts/5944 ; DOI : 10.4000/ejts.5944

This text was automatically generated on 16 February 2020

(c) Some rights reserved / Creative Commons license 


\title{
Transformation of the Turkish Diyanet both at Home and Abroad: Three Stages
}

\author{
Ahmet Erdi Öztürk
}

Since the 1937 Constitutional amendment, Turkey defines itself as a secular state despite its Ottoman legacy on which it was founded and a Sunni Muslim majority. On the face of this clear Constitutional standing, secularism is still a broadly debated issue due to the promotion of fundamentally different opinions on state-religion relations by various socio-political groups. In the current context, how much of Turkish secularism remains in its initial form is open to debate despite the Constitutional protection. The Directorate of Religious Affairs (Diyanet) holds the centre stage in the secularism debate as an institution which, through its own journey, explains the historical development of that debate. In an idiosyncratic way, Diyanet was officially formed in 1924 by law number 429 before the endorsement of secularism in the Constitution. The Law states the raison d'être of Diyanet as "management of prayer houses and dealing with the belief and practices of Islam which falls outside the regulations legislated and executed by Grand National Assembly". In practice however, there has always been institutions to manage religions during both Byzantine and Ottoman times. In a general framework, Diyanet has been a reincarnation of institutional management of religions and as a central institution since the foundation of the Republic; it has acted as both the cause and effect in the debates pertaining to state-society-religion relations.

There is a significant scholarly literature on the issues of religions, religious institutions and their multidimensional influence on society and political machinery. Fox (2008) was one of the scholars who have let the genie out of the bottle by unearthing that every state instrumentalises religion, but some of them exaggerate the mark through some parameters. The variety of roles that religion play have been analysed broadly both in relation to domestic politics (Koesel 2014; Gill 1998; Gurses 2015; Kuru 2011; Gunning 2008) and to foreign policy (Sandal \& Fox 2013; Haynes 2008; Warner \& Walker 2011; Hurd 2007; Snyder 2011; Marie 2017). Gill and Keshavarzian (1999) have confirmed the importance of religious institutions in social, economic and 
political arenas, and made inroads to revealing the roles and functions of religious institutions. While Mandaville (2010) underlines the impact of religious institutions on the regulation of individuals' socio-political life via management of religion, some others bring forward the positive roles that religious institutions have played in democratic transitions in South Asian (Cheng \& Brown 2006), Catholic (Gill 2008; Philpott 2004), and Muslim majority countries (Stepan \& Linz 2013). Furthermore, the variety of religious institutions and their roles have been subject to studies on religion and globalisation (Haynes 2009), transnationalism (Djupe \& Gilbert 2008), and conflict management (Ghose \& James 2005). A different perspective is laid out by Sandal (2011) who argues that a religious institution acts as an epistemic community through its clergy, providing expertise that informs and even programs a political agenda to a certain interest group or even an entire body of adherents. A cross examination of these ideas reveal that Diyanet's position, role and symbiotic relationship with the Turkish state do not give this religious state institution its proper position in any of these perspectives. Therefore, the question "what kind of a religious institution is Diyanet?" remains a kick off sentence for a vigorous research which it undoubtedly deserves.

Maritato (2015: 434) clearly expresses the founding mentality of Diyanet which reflects the early Republican elite's positivist-nationalist perspective on religion in the public sphere. In a similar vein, while Gözaydın (2008: 13) defines Diyanet as a laik ${ }^{1}$ administrative unit of Turkish Republic charged with the duty of enlightening the society about religion and conducting Islamic practices, Öktem (2012: 40) argues that Diyanet is a government body of laik Turkey which deals with all religious issues of Sunni citizens on behalf of the state. Lord (2017: 49) focuses on Diyanet's monopoly on controlling Sunni Islamic life in Turkey since its foundation, while Çitak (2013: 169) places the focus on the grounds of foreign policy and deals with the role of Diyanet as an external instrument to build and consolidate national unity among the Turkish communities abroad, since the 1970s. In recent studies it has also been argued that the instrumentalisation of Diyanet in domestic and foreign policy has been upsetting the secular sections of Turkey (Öztürk \& Sözeri 2018) due to its role of imposing religion and legitimizing government policies through a religious discourse since the beginning of the 2000s (Öztürk 2016).

Most studies on Diyanet do not carry out a deep engagement and elaboration regarding theories of secularism and approaches to religion-politics relations, but these are necessities in examining Turkey's unique understanding of laiklik ${ }^{2}$ for the society and Diyanet as an institutional arm of it. In a similar vein, most scholarly attempts to explore the various activities of Diyanet in different periods and geographies do not touch upon the question of what kind of religious institution Diyanet is by creating a theoretical link with the previous literature on religious intuitions. On the face of such shortcomings, one thing is clear: Diyanet is a transnational state apparatus with an ever-changing nature depending on the Turkish governments' preferences in terms of domestic and foreign policy. In such a context, this article aims to discuss the various roles and activities of Diyanet in the domestic and foreign policy of Turkey as a state institution of religion. It builds a claim that Diyanet should be studied in three different stages in which its characteristics as a religious institution and the overall laik settings of Turkey have changed. 
Among many social and political factors and their overall impact on the state, laiklik and the roles of Diyanet have recently been changing in Turkey. The main turning points were the results of critical junctions such as; coup d'état and others states of exception, and have affected the understanding and implementations of laiklik through changes in the structure, impact and assigned positions of Diyanet. In order to gain a deeper understanding of these, this article analyses the various states of Turkish laiklik and the transformation of Diyanet within an interwoven structure of Turkish domestic and foreign political life. Therefore, it begins with an overview of the establishment of laiklik and foundation of Diyanet in the early Republican period and explains the turning points of laiklik and Diyanet throughout modern Turkish history. Secondly, it addresses the transformation of Diyanet's transnational activities in the three aforementioned stages.

\section{Periodization of Turkish Laiklik and Diyanet from the Early Republican Period to AKP Times}

Diyanet, like many other Republican institutions, was a continuation of Ottoman institutions as part of a reformed structure. When the Republic was founded, Law 429 was proposed by Siirt deputy Halil Hulki Efendi and 50 other Parliament members. It abolished the Ministry of Sharia and Pious Foundations and General Staff on 3 March 1924 and established Diyanet in its place. This interference indicates the importance of religious issues for the new-born Republic and exhibits the mindset of the Republican elite regarding state-religion relations. In the motion of this law, the following arguments were made:

Religion and army being involved in political currents invites inconveniences. This reality has been accepted a ground rule by all the civilized nations and governments. For this reason, the existence of the already-obsolete Ministry of Sharia and Pious Foundations, as well as Ministry of General Staff in the political body of the Republic of Turkey, which undertakes the mission of providing a new entity, would not be withstanding. Upon abolition of the Ministry of Sharia and Pious Foundations, it is a natural result that all the pious foundations would be yielded to the people and governed accordingly. (Gözaydın 2009: 26).

Diyanet has inherited the historical legacy of the Ottoman Empire regarding statereligion relations and has become an existential institution for the Republic. So there has been coexistence between Diyanet and the overall nature of Republic in harmonious, tense and conflictual ways. Diyanet was founded to regulate the collective and individual manifestations of Islam in public and private spaces, and to manage all Islamic institutions. In this regard, it is fair to argue that the new Republic had a monopolistic and interventionist mind-set on the management of religious issues. Diyanet has always had the upper hand in religious debates vis-à-vis the civic perspectives when it came to the matter of legitimacy.

The first phase started in 1924, when Turkey was not constitutionally laik, and lasted until 1960. In the formative years of the Republic, the founding elite positioned Diyanet in recognition of its importance. However, it was not given a ministerial status in order to deny it a policy making position. Therefore, it would be fair to say that the Diyanet was founded as an administrative unit from the very beginning, which is a defining characteristic of Turkish secularism. Seemingly, assigning religious affairs to an entity within the technical administration status falls in line with the secular settings of the 
country. However, it gives the government huge leverage on religious discourse and practice and renders the mechanism hierarchical as it favours the government. While the government decided on religious policies, Diyanet could only inform the government on religious issues and act as an administrative body. Viewed horizontally however, Diyanet exercises a huge influence on the society since it creates and disseminates official Islam and manages the places of worship. It would be fair to say that while vertically incompetent since it cannot decide on policies, Diyanet is extremely competent from a horizontal perspective.

The Constitutional amendment that made laiklik official set a turning point regarding religion-politics and society relations in Turkey. "The religion of the state is Islam" clause was removed from the Constitution in 1928 and in 1937, laiklik was introduced as one of the fundamental constitutional characteristics of the new regime. The historical formation of Diyanet indicates that the Turkish conception of secularism, laiklik, presents itself as the control of religion by the state rather than separation of state from religion(s) as claimed by the Kemalist discourse. Frequently, Diyanet has acted as the guardian of the existing regime, bringing Islamic legitimacy to it. As a state apparatus, Diyanet securitized government policies and made them into undebatable matters of high politics. There exists occasionally seeking approval from an entity that they designed as the religious organization, as well as using it as the propagator of the official version of Islam and the inspector of different groups; however, here, the ultimate goal, unlike future policies, is to disengage religion from other social organizations and functions as much as possible, in line with the action plans on structural social changes. All in all, Turkish secularism has never been intended as the independence or impartiality of religious matters from state policies. Under the influence of vulgar positivism, the founders of the Republic perceived religion as obsolete as it was a rival, even a danger. However, banning religious elements from the public space altogether or staying out of the management of the religious field was not an option for the state centric modernization of Turkey. Therefore, the founders of the Republic seem to have assigned two major functions to Diyanet; providing a public service by organizing and leading religious practice and protecting the laik order by bringing legitimacy to it. A by-product of this institutionalization was the ability to keep unwanted civic formations, such as communities and Sufi orders, under check by drawing red lines on religious matters. The Diyanet has been a vital institution in the social engineering processes of the ruling elite by creating an "accepted" Islam which was envisaged as a religion that is ultimately passive in the public space. Thus, the laik Turkish state has defined an official Islam under the body of Diyanet and designated the other Sunni religious communities as unofficial (Akgönül 2005).

The role and the position of Diyanet are also related to the lack of an organized clergy in (Sunni) Islam unlike the church in (Catholic) Christianity ${ }^{3}$. Therefore, it is one of the primary reasons that the state considers religious service as a public duty. The Diyanet has undertaken this public service as a response to a major public need and played an essential role in the production and reshaping of religiousness in Turkey during the Republican period. At this point, a major criticism towards Diyanet is about the organization's exclusive focus on Sunni Muslims, taking the Hanafi School of jurisprudence as its benchmark. This preference is reflected in the practice of religious service as well as any publication or broadcast performed by Diyanet. Nevertheless, it is evident that other groups of Islam exist in Turkey, such as Alevis, Sunni Shafiis or Jafaris, even though their exact numbers are unknown. For this reason, the primary 
issue regarding the state's provision of religious service in Turkey is its exclusivist nature. However, the existing situation does not lack legal defence: The religious services for Armenian, Jewish and Greek citizens, who constitute the major religious minorities in Turkey, are represented by their own congregations in line with the Lausanne Peace Treaty clauses. Then again, this clause leaves out certain religious communities that are not considered minorities in the Lausanne Peace Treaty, such as; Assyrians, Chaldean and Yezidis. Alevis are for instance neither regarded as minorities in any legal framework nor as regular (Sunni) Muslims. These general characteristics of Diyanet and the Turkish understanding of laiklik was formed in the founding period of the Republic and has continued without fundamental changes.

The second period of Diyanet and the Turkish understanding of laiklik started at a critical junction in recent Turkish history; the 1960 coup d'état and the following Constitution of Turkey, and ended in early 2000s. In this period, Diyanet was again regulated by a Constitutional article (154) which expanded its activity areas. The relevant law came into force after a series of long debates in 1965 in the Grand National Assembly of Turkey as Law $n^{\circ} 633$ on the Foundation and Duties of Diyanet. Through this law, the duties of Diyanet were designated as; overseeing affairs concerning belief, worship and moral foundations of Islam, informing the public on religion, and administering places of worship. As stated by Ali Bardakoğlu, a former president of the institution, Diyanet, as a public entity, has a special role in producing and conveying religious knowledge. (Bardakoğlu 2008). The law gave Diyanet broader jurisdiction and provided it with higher levels of administrative and financial autonomy. Furthermore, it enlarged the organizational structure of Diyanet, resulting in the creation of the High Council for Religious Affairs [Din İsleri Yüksek Kurulu] and the re-organization of numerous other departments. These regulations were not in conflict with Turkish laiklik, which was primarily defined as the management of religion.

In the second period, the functions of Diyanet and the understanding of Turkish laiklik was transformed at yet another critical junction. After the coup d'état of 1980, Diyanet was assigned the duties of consolidating national solidarity and unity while undertaking the functions assigned by its special statute placed in Article 136 of the following (1982) Constitution (Öztürk 2016). The emphasis on solidarity and national unity were strongly related to the decade long conflict in the 1970s, which left a huge civilian death toll and a deeply divided society. The new administration after the coup considered religion as an instrument to unite the society and resist against the spread of communism, which was popular in 1970s' Turkey. Therefore, the Diyanet was placed in a position to carry out these duties intertwined with the management of religion. Instrumentalisation of religion for greater societal matters was added to Diyanet's raison d'être which brought a new function; promoting unity of Turkey and supporting national solidarity using the tenets of Islam.

During the two periods, the issue of Sunni exclusivism and resulting discrimination against Alevis are quite important. There is a huge variety of interpretation on Alevism between the Alevi groups themselves and outside their communities. Alevism claims the primacy of Caliph Ali over the other leading figures of his time, after the passing of Islamic Prophet Muhammad, and is attributed a privileged position in religion. Alevism involves more mystical and spiritual elements in its faith structure(s) as a sect outside the major Sunni groups. More importantly, it was denied full representation in public spaces during Ottoman times and not accepted as a manifestation of "true Islam". 
Meanwhile, Diyanet claims that it does not treat Alevis and Sunnis differently as these two groups do not have any differences in religious matters other than some local traditions and beliefs. It is frequently stated that Diyanet is founded with a role above different beliefs, sects and congregations, and aims to provide service to the members of different belief systems. Equally, in recent court cases, the administration persistently emphasizes that the services provided are for every adherent of the Islamic faith, therefore, they are not specific in nature and above different religious denominations. This is the official line of the Turkish state and is employed consistently. According to Sait Yazıcıoglu, a former chairman of Diyanet, the institution was founded in order to provide religious service for all Muslims regardless of sectarian orientation. The principles of Islam regarding belief, worship and morality are well defined. The Qur'an that all Muslims of any denomination recognize as the ultimate Holy Scripture is evident. Informing the public on religion in line with the Qur'anic rules, therefore providing religious and national unity, are the functions of the Presidency of Religious Affairs, as assigned by the law (Gözyadın 2009: 13). Another former president of Diyanet, Mehmet Nuri Yllmaz, said in a press meeting on 24 March 1993, when he was still president, that the Presidency was a Constitutional organization that embraced all the Muslim people of the country and stated that there was no serious issue in today's Turkey regarding a distinction between Alevis and Sunnis (Gözaydın 2009: 37). As stated by Prof. Mehmet Görmez, yet another President of the institution

the Diyanet cannot assign a religious status; this status may only be defined by the very followers of this belief. We have always had two red lines that we have never renounced. One of them is to define Alevism as a non-Islamic belief, and the other is to define cemevis as an alternative to mosques, as a temple of another belief. (Öztürk 2016: 637.)

Therefore, another point of conflict has been that between the demands of Alevi groups and the official stance of the authorities in terms of the legal status of the cemevis, the gathering houses of Alevis. Cemevis are officially recognized as cultural centres; a token of cultural wealth with a distinctive cultural and mystical identity that has to be preserved. The core debate on that matter is whether they constitute alternatives to or equivalents of mosques. However, the decisions taken by the European Court of Human Rights regarding this issue give the judgment that the freedom of religion, as it is guaranteed by the European Convention on Human Rights, does not give a judicial discretion to states on the legitimacy of religious beliefs or the ways the religious beliefs are expressed. As per three decisions taken on the issue in "Manoussakis and others vs. Greece" (26 September 1996); "Hasan and Chaush vs. Bulgaria" (26 October 2000), and "the Metropolitan Church of Bessarabia and others vs. Moldova" (13 December 2001); no state has the authority to question any party's definition of their own beliefs. Accordingly, on 26 April 2016, the European Court of Human Rights, with its decision no. 6269/10, judged that Articles 9 and 14 of the European Convention on Human Rights were violated by Turkey. Therefore, it has been decided by the international judicial authority that the demands of services regarding the Alevi Islamic belief should be given as public service, the cemevis be given the status of places of worship, the Alevi religious leaders be instated as public officers, schools to be opened in order to train religious leaders (dede-baba) to yield their Islamic beliefs to coming generations of the Alevi community, and allocation of an annual share from the public budget for the services to be provided. 
The third period started with AKP rule in 2002 and proceeded with social engineering policies in line with AKP's socio-political imaginary. A key apparatus for the policies carried out through political and legal organizations is unsurprisingly Diyanet. An amendment to Law no. 633 on the Foundation and Duties of Diyanet had entered into force in 1976, but it was rescinded by the Constitutional Court in 1979. The next amendment was made 31 years later, in 2010. It is striking that the Law that had been rescinded was almost fully put back into force after 31 years, preserving its initial approach with structural changes such as linking the institution to the President of the Republic instead of the Prime Minister's Office. This approach proves that the AKP, just like CHP, the founding party of the Republic, desires to control the Diyanet and use it to build and maintain the desired social order.

In this period, Diyanet has gone through another extension in the scope of its services and has started to give spiritual guidance in correctional facilities, detention centres, nursing homes, and medical facilities. In order to guide families, women, youth and others in society on religious matters, it allocated a budget of 4 million Turkish liras (TL) to publications against moral degeneration in its 2015 Performance Program. In the relevant document, it was stated that 3.7 million TL was allocated for the objective of taking an active role in the resolution of social issues, 8.5 million TL for increasing productivity, 1 million TL for creating and propagating an objective perception of Islam globally, 76 million TL for reaching all layers of society with religious services, 34 million TL for activities abroad, and 61 million TL for religious education activities. Beyond that, a TV channel, named Diyanet TV, was founded in 2012 to broadcast around the clock and disseminate Diyanet's perspective on religion and more. Its labour force exceeds 120,000 imams and other civil servants and has a budget of over 2 billion TL (Öztürk 2016).

Consequently, it would be fair to argue that the three critical junctions in contemporary Turkish history affected the role and position of Diyanet alongside the Turkish understanding of laiklik. In this regard, both the 1960 and 1980 coup d'états have enlarged the spheres of influence and control of Diyanet and assigned new roles to it, such as enlightenment of society, consolidation of national unity and legitimation of Turkish nationalism, and coaching the society on religious issues. Yet, it would again be fair to argue that the most fundamental change regarding the activities of Diyanet and the role of religion occurred during AKP rule. In this regard, as noted previously, Diyanet's budget, administrative capacity (due to legal reforms in 2010) and activities have been gradually expanding, and its policies have been tightly synchronised with the policies of the AKP. Even though Diyanet's activities have never been independent from the governments throughout the republican history, the last remaining elements of autonomy have been lost in the AKP period as the institution has been turned into an extension of the Party.

\section{Transnationalisation of Diyanet and the three periods abroad}

Even though Diyanet was officially founded with the aim of serving Turkish citizens within the borders of Turkey, the changing conditions at home and abroad forced Diyanet to become a transnational state apparatus. Starting in 1971, Diyanet began providing religious services for Turkish citizens abroad and the Turkic societies. 
Currently, Diyanet is present abroad with religious affairs consultants within embassies and religious affairs attachés within consulates of the Republic of Turkey in countries with citizens and kin (Öktem 2012: 51). This transnationalisation became a necessity for two main reasons: The first one is the huge wave of migration from Turkey to European countries starting in the 1960s. Hundreds of thousands of Turkish citizens have migrated to Germany, France, the Netherlands, the UK, Sweden and other European countries seeking job opportunities and a small number of them looking for political asylum. These migrants caused two responses from the Turkish state and the host countries. The Turkish state realized the need to establish links with these migrant groups and maintain ties with them. The host countries, on the other hand, acknowledged that the "Muslim" migrants needed religious service; preferably from a moderate actor to avoid any disruption in their internal secular or religiously different social environments (Öztürk \& Sözeri 2018). Therefore, the Diyanet was assigned by the Turkish state to provide such services and was mostly welcomed by the host countries with an aim to fill the void in terms of religious discourse and services to inhibit the influence of radical Islamic groups.

Based on these priorities, the first stage of Diyanet's transnationalisation mainly started in continental Europe. The Turkish state followed two different routes to reach its citizens abroad. Firstly, Turkey started to appoint religious attaches to the embassies and consulates of Turkey from Diyanet as religious diplomats in several cities of Germany, France and the Netherlands. The main duties of these attaches are serving Turkish citizens regarding their religious needs, such as supplying holy books, conducting religious meetings and establishing coordination between host and home countries. These attaches were appointed to promote the Turkish state discourse, Turkish nationalism and Turkish understanding of Islam among the Turkish diaspora groups. Yet, these official attaches' spheres of influences were limited and therefore, Turkey put the second approach into action through the establishment of a religious foundation under the control of Diyanet. In 1978, Religious Services Councillorship [Din Hizmetleri Müşavirliği] were established in 18 Turkish Consulates in Germany, and 21 Attachés for Religious Services [Din Hizmetleri Ataşeliği] were appointed by Diyanet at the Turkish embassies and consulates in Europe, the Unites States and Australia (Öztürk \& Sözeri 2018: 23). In 1984, the first foundational branch of Diyanet was founded in Germany under the name of the Turkish-Islamic Union for Religious Affairs (Turkish Islamische Union der Anstalt für Religion - DİTіB). With headquarters in Cologne, DITIB was controlling more than 900 mosques all over Germany in 2017. In a similar fashion, Turkish Diyanet opened other organizations in other countries in the 1980s, such as the France DITiB (Union des Affaires Culturelles Turco-islamiques) and the Dutch branch of Diyanet. At this point, one should keep in mind that most Turkey-originated diaspora members are either dual citizens or hold permanent residence in these countries (Öztürk \& Gözaydın 2018). Therefore, they have certain capacities to influence both Turkish and host countries' socio-political life. This provides them with the ability to establish transnational links that go beyond state borders and gives Turkey spheres of influence beyond its borders.

The second stage of transnationalisation of Diyanet started in the first years of the post-Cold War period with an extension of Diyanet in the Balkan Peninsula and Asian Turkic states. In the beginning of the 1990s most Balkan and Asian Turkic states had reached independence with the fall of communist regimes and identified a need for religious services for their own Muslim populations. Therefore, most of these countries 
established umbrella institutions like Diyanet but their financial capacities and human resources were limited. The primary reason that they went into a variety of cooperation agreements with Turkey's Diyanet was to empower their organizational structures, to fill the void in the field of religion and to prevent some Salafi and Wahhabi groups from gaining grounds. Turkey's laik state identity played a determinant role in this process. Bulgaria, Albania, Macedonia, Azerbaijan, Kirgizstan, Uzbekistan and Turkmenistan invited the Turkish Diyanet and eventually, Diyanet reached the consultancy level [müsteşarlk], which is the highest bureaucratic level in these countries. With this affiliation, Diyanet started to play supervising roles in these countries and give financial assistance within the conditions of mutual agreements.

The third stage in the transnationalisation of Diyanet started in the recent years of the AKP. AKP did not only transform the domestic political structure in Turkey, but also affected the foreign policy and Diyanet as a result. The praxis of change in foreign policy was formulated and put into effect by Ahmet Davutoğlu, the former Prime Minister and Foreign Minister who argued that Turkey could become a global power in the post-Cold War context as long as it followed an expansionist foreign policy based on an Islamist ideology. Davutoğlu focuses on the ontological differences between Islam and other civilizations, particularly the West, and asserts that these differences cause an obstacle for the study of contemporary Islam as a subject of social sciences, especially in international politics. This ideological orientation brought a fundamental axial dislocation for Turkish laiklik and foreign policy mentality. In other words, this new orientation aims to utilize Islam as a power-element of foreign policy by making Sunni Islam more visible and, therefore, making Diyanet a major tool in foreign policy.

At this point, it should be noted that under AKP rule DiтiB has started to work as a parallel diplomacy machine of the Turkish state and has a double-sided role. On the one hand, the DітїB is becoming the interlocutor of the states of Western Europe, especially in France, Germany, Belgium and Holland, indicating its willingness to become the representative of European Islam and imposing the Turkish model. This means that it has become the visible face of Turkish Islam's AKP understanding. On the other hand, alongside this function of identity promotion, the role of the DITIB remains the identity maintenance of the Turks of Europe, through the centralised sermons where the message from the centre to the periphery remains the same: stay Turk and act in the world according to the interest of the Turkish state. With regard to this important function of the maintenance of identity, the function of the imam as intermediate agent is important. The Imam transmits the message of identity and normative politics in his official functions but also is an informal contact with the faithful, in Turkey as well as in Europe.

Diyanet has reached the peak of its activities under AKP rule, gaining new duties in line with new state policies and becoming the mouthpiece of the AKP abroad (Çitak 2013). It started building mosques from the Balkan Peninsula to North America and became more visible with its 61 branches in 36 countries including, Lithuania, Russia and Belarus. Furthermore, it has been publishing and distributing the Quran and other religious books in 28 languages and financially supporting official Islamic representative institutions in the Balkans, Continental Europe and Africa. It has also been supplying educational and material support for imams in foreign countries and organising official gatherings, such as Eurasia Islamic Council, Balkan Countries Islamic Council, Latin America Countries' Muslim Summit and African Religious Leaders 
Summit. Therefore, one might claim that in the third stage, Diyanet has started to play a leading role among the other Muslim umbrella organisations. Furthermore, in this third stage, Diyanet started to exceed its jurisdiction and do things outside the remit of religious service. Allegations of Diyanet gathering intelligence about anti-AKP diaspora groups in some European countries, which was justified under the mission of "protecting the national solidarity and unity" given by the 1982 Constitution, created problems in the host countries and made them take measures against it. For instance, Austria recently passed an Islam law which stipulates that in Austria, an officer from another country will not be permitted to deliver religious services. Therefore, 65 religious officers of Diyanet will come back to Turkey in a year, and this practice will end. Again, financial resources for places of worship may only be provided from within Austria. It would be fair to claim that Diyanet's intense interest in Western Europe has to do with AKP's ambitions on maintaining control over its electoral body in the diaspora as much as delivering the objective religious service that Turkish citizens need.

\section{Conclusion}

All in all, in this article, I tried to define the Turkish understanding of laiklik and the transformation of Diyanet through turning points in contemporary Turkey and legal regulations in the Turkish Constitution(s). Diyanet, as an important yet subservient state institution, has been heavily influenced by any major policy change in Turkey. Turkish laiklik, with its Western and moderate outlook, and Diyanet, with its established institutional capacity, have been utilized for political purposes at home and abroad. Drawing on the explanatory framework of Diyanet's historical journey, this study demonstrates that Diyanet has gone through three different stages in terms of its domestic and international activities. The transformation of Turkish understanding of laiklik and particularly the rise of AKP succeeded in integrating a religious discourse into various fields of policymaking and have expanded Diyanet's spheres of influence more than any of its predecessors. It can be argued that these changes would not be feasible without replacing the secular state identity with a Sunni Islamic one. The promotion of Sunni Islam among Turkish and Muslim communities abroad has become both an objective and a means to exercise influence on the Muslim minorities, which in practice means socio-political leverage in the host countries.

\section{BIBLIOGRAPHY}

Akgönül, Samim (2005). Religions de Turquie, religions des Turcs. Nouveaux acteurs dans l'Europe élargie, Paris, L'Harmattan.

Akkoyunlu, Fevzi Karabekir (2014). "The rise and fall of the hybrid regime: guardianship and democracy in Iran and Turkey" (Doctoral dissertation, The London School of Economics and Political Science [LSE]). 
Avci, Gamze (2005). "Religion, transnationalism and Turks in Europe," Turkish Studies 6(2), p. 201-213.

Balci, Bayram (2014). "Turkey's Religious Outreach in Central Asia and the Caucasus," Current Trends in Islamist Ideology 16, p. 65-83.

Bardakoğlu, Ali (2008). "The structure, mission and social function of the Presidency of Religious Affairs (PRA)," The Muslim World 98(2-3), p. 173-181. DOI: 10.1111/j.1478-1913.2008.00217.x.

Başer, Bahar; Öztürk, Ahmet Erdi (2017). Authoritarian politics in Turkey: elections, resistance and the AKP, London, IB Tauris.

Bozarslan, Hamit (2003). "Alevism and the myths of research: the need for a new research agenda," Turkey's Alevi enigma: a comprehensive overview 88, p. 3-15.

Brown, Deborah A.; Cheng, Tun-jen (2012). "Religious relations across the Taiwan Strait: Patterns, alignments, and political effects,” Orbis 56(1), p. 60-81. DOI: 10.1016/j.orbis.2011.10.004.

Bruce, Benjamin (2015). Governing Islam abroad: the Turkish and Moroccan Muslim fields in France and Germany (Doctoral dissertation, Paris, Institut d'études politiques).

Bruce, Benjamin (2013). "Not quite in, not quite out: Islamic organizations in France and Germany and their ties to their states of origin," in Islamic Organizations in Europe and the USA, London, Palgrave Macmillan, p. 129-149.

Çitak, Zana (2013). "The institutionalization of Islam in Europe and the Diyanet: the case of Austria,” Ortadoğu Etütleri 5(1), p. 167-182. URL: http://orsam.org.tr//d_hbanaliz/makale7.pdf.

Davison, Andrew (2003). “Turkey, a ‘secular' state? The challenge of description,” The South Atlantic Quarterly 102(2), p. 333-350.

Djupe, Paul A.; Gilbert, Christopher P. (2008). The political influence of churches, Cambridge, Cambridge University Press. DOI: 10.1017/CBO9780511819117.

Dressler, Markus (2008). "Religio-secular metamorphoses: The re-making of Turkish Alevism," Journal of the American Academy of Religion 76(2), p. 280-311.

Erdem, Gazi (2008). "Religious Services in Turkey: From the Office of şeyhülislām to the Diyanet," The Muslim World 98(2-3), p. 199-215.

Ersahin, Seyfettin, (2008). "The Ottoman Foundation of the Turkish Republic's Diyanet: Ziya Gokalp's Diyanet Ishlari Nazârati," The Muslim World 98(2/3), p. 182.

Es, Murat, (2013). “Alevis in cemevis: religion and secularism in Turkey," Topographies of faith: Religion in urban spaces, p. 25-43.

Fox, Jonathan; Sandal, Nukhet (2013). Religion in international relations theory: interactions and possibilities, London, Routledge. DOI: 10.4324/9780203694435.

Fox, Jonathan (2008). A world survey of religion and the state, Cambridge, Cambridge University Press. DOI: 10.1017/CBO9780511993039.

Gill, Anthony (2008). Rendering unto Caesar: the Catholic Church and the state in Latin America, Chicago, University of Chicago Press.

Gill, Anthony (2001). "Religion and comparative politics," Annual Review of Political Science 4(1), p. 117-138. DOI: 10.1146/annurev.polisci.4.1.117. 
Gill, Anthony; Keshavarzian, Arang (1999). "State building and religious resources: An institutional theory of church-state relations in Iran and Mexico," Politics \& Society 27(3), p. 431-465. DOI: 10.1177\%2F0032329299027003006.

Göle, Nilüfer (2005). “La laïcité républicaine et l'islam public,” Pouvoirs 4, p. 73-86.

Göle, Nilüfer (1997). "Secularism and Islamism in Turkey: The making of elites and counterelites," The Middle East Journal, p. 46-58.

Gormez, Mehmet (2008). "The Status of the Presidency of Religious Affairs in the Turkish Constitution and its Execution," The Muslim World 98(2-3), p. 242-248.

Gözaydın, İstar (2014). “Management of religion in Turkey: the Diyanet and beyond," Freedom of Religion and Belief in Turkey, p. 10-35.

Gözaydın, İştar (2010). "Religion as Soft Power in the international relations of Turkey,” IPSAECPR Joint Conference: Whatever Happened to North-South?, Sao Paulo 19-21 Feb. 2011. URL: http://paperroom.ipsa.org/papers/view/26422.

Gözaydin, İștar (2008). "Religion, Politics, and the Politics of Religion in Turkey," in Dietrich Jung \& Catherina Raudvere (eds.), Religion, Politics, and Turkey's EU Accession, New York, Palgrave Macmillan, p. 159-176. DOI: 10.1057/9780230615403.

Grigoriadis, Ioannis,N (2007). “Türk or Türkiyeli? The reform of Turkey's minority legislation and the rediscovery of ottomanism," Middle Eastern Studies 43(3), p. 423-438.

Gunning, Jeroen (2008). Hamas in politics: democracy, religion, violence, London, Hurst/Columbia University Press.

Gurses, Mehmet (2015). “Transnational ethnic kin and civil war outcomes," Political Research Quarterly 68(1), p. 142-153. DOI: 10.1177\%2F1065912914554042.

Haynes, Jeffrey (2009). "Conflict, conflict resolution and peace-building: The role of religion in Mozambique, Nigeria and Cambodia," Commonwealth \& Comparative Politics 47(1), p. 52-75. DOI: $10.1080 / 14662040802659033$.

Haynes, Jeffrey (2008). "Religion and foreign policy making in the USA, India and Iran: towards a research agenda," Third World Quarterly 29(1), p. 143-165. DOI: 10.1080/01436590701739668.

Hurd, Elizabeth Shakman (2007). “Theorizing religious resurgence," International Politics 44(6), p. 647-665. DOI: 10.1057/palgrave.ip.8800212.

Keyman, E. Fuat (2007). "Modernity, secularism and Islam: The case of Turkey,” Theory, culture \& society 24(2), p. 215-234.

Koesel, Karrie J. (2014). Religion and authoritarianism: Cooperation, conflict, and the consequences, New York, NY, Cambridge University Press.

Korkut, şenol (2010). "The Diyanet of Turkey and its activities in Eurasia after the Cold War," Acta Slavica Iaponica 28, p. 117-139.

Kuru, Ahmet T. (2011). Pasif ve dışlayıcı laiklik: ABD, Fransa ve Türkiye (Passive and exclusivist secularism: the US, France and Turkey), Istanbul, Bilgi University Press.

Lord, Ceren (2017). "Between Islam and the nation; nation-building, the ulama and Alevi identity in Turkey," Nations and Nationalism 23(1), p. 48-67. DOI: 10.1111/nana.12238.

Lord, Ceren (2018). Religious Politics in Turkey: From the Birth of the Republic to the AKP, Cambridge, Cambridge University Press. 
Mardin, şerif (2005). "Turkish Islamic exceptionalism yesterday and today: Continuity, rupture and reconstruction in operational codes," Turkish Studies 6(2), p. 145-165.

Maritato, Chiara (2015). “Performing Irşad: Female preachers' (vaizeler's) religious assistance within the framework of the Turkish state," Turkish Studies 16(3), p. 433-447. DOI: 10.1080/14683849.2015.1056520.

Öktem, Kerem (2012). “Global Diyanet and multiple networks: Turkey’s new presence in the Balkans," Journal of Muslims in Europe 1(1), p. 27-58. DOI: 10.1163/221179512X644042.

Orhan, Özgüç (2013). “The paradox of Turkish secularism,” Turkish Journal of Politics 4(1), p. 27-47. Ozkan, Behlül (2014). “Turkey, Davutoglu and the idea of pan-Islamism,” Survival 56(4), p. $119-140$.

Öztürk, Ahmet Erdi; Gözaydın, İstar (2018). “A Frame for Turkey’s Foreign Policy via the Diyanet in the Balkans," Journal of Muslims in Europe 7(3), p. 331-350.

Öztürk, Ahmet Erdi; Sözeri, Semiha (2018). "Diyanet as a Turkish foreign policy tool: Evidence from the Netherlands and Bulgaria," Politics and Religion 11(3) p. 624-648. DOI: 10.1017/ S175504831700075X.

Öztürk, Ahmet Erdi (2016). “Turkey's Diyanet under AKP rule: from protector to imposer of state ideology?," Southeast European and Black Sea Studies 16(4), p. 619-635. DOI: 10.1080/14683857.2016.1233663.

Özyürek, Esra (2009). “'The light of the Alevi fire was lit in Germany and then spread to Turkey': A transnational debate on the boundaries of Islam," Turkish Studies 10(2), p. 233-253.

Ozzano, Luca; Maritato, Chiara (2018). "Patterns of Political Secularism in Italy and Turkey: The Vatican and the Diyanet to the Test of Politics," Politics and Religion, p. 1-21.

Philpott, Daniel (2004). "Christianity and Democracy: The Catholic Wave," Journal of Democracy 15(2), p. 32-46.

Sandal, Nukhet Ahu (2011). "Religious actors as epistemic communities in conflict transformation: The cases of South Africa and Northern Ireland," Review of International Studies 37(3), p. 929-949. DOI: 10.1017/S0260210510001592.

Snyder, Jack (2011). Religion and international relations theory. New York, Columbia University Press.

Stepan, Alfred ; Linz, Juan J. (2013). "Democratization Theory and the 'Arab Spring'," Journal of Democracy 24(2), p. 15-30. URL: https://www.journalofdemocracy.org/sites/default/files/ Stepan-24-2.pdf.

Sunier, J. T.; Landman, N. (2011). Diyanet. The Turkish Directorate for Religious Affairs in a changing Environment, Amsterdam/Utrecht, VU/UU.

Ulutas, Ufuk (2010). "Religion and secularism in Turkey: The dilemma of the directorate of religious affairs," Middle Eastern Studies 46(3), p. 389-399.

Veinstein, Gilles, « Les Ottomans : fonctionnarisation des clercs, cléricalisation de l'État? », in Iogna-Prat, Dominique ; Veinstein, Gilles (dir.), Histoire des hommes de Dieu dans l'islam et le christianisme, Paris, Flammarion, 2003, p. 179-202.

Warner, Carolyn M.; Walker, Stephen G. (2010). "Thinking about the role of religion in foreign policy: A framework for analysis," Foreign Policy Analysis 7(1), p. 113-135. DOI: 10.1111/j.

1743-8594.2010.00125.x. 
Yanaşmayan, Zeynep (2010). "Role of Turkish Islamic Organizations in Belgium: The Strategies of 'Diyanet' and 'Milli Görüş', Insight Turkey, p. 139-161.

Yurdakul, Gökçe; Yükleyen, Ahmet. (2013). “Islam, Conflict, and Integration: Turkish Religious Associations in Germany," in Turkish Immigrants in Western Europe and North America, London, Routledge, p. 88-102.

\section{NOTES}

1. The word laik expresses Turkish secularism which sees religion as obsolete in terms of regulating public spehere and irrevelant when it comes to political legitimacy.

2. The word, laiklik roughly stands for Turkish secularism

3. Even though, from my point of view there has never been a clergy in (Sunni) Islam, some prominent scholars, such as Gilles Veinstein, argued that the Ottomans managed to "clericalize" Sunni Islam and their own state. Further discussion on this issue is beyond the scope of this paper. Yet, for additional reading see Veinstein 2003.

\section{ABSTRACTS}

This articles focuses on the historical evaluations of Turkey's Presidency of Religious Affairs (the Diyanet) since its foundation and tries to explain the importance of some of the substantial turning points of Turkey's history on the operasonalisations of the Diyanet both at home and abroad. Therefore, it seeks answers of these very fundamental research questions; What is the significance of the Diyanet in terms of both state and religion relations, and politics in Turkey? What are the differences of the Diyanet's impact and functions compare to its foundation period? Why and how does Turkey use the Diyanet as a foreign policy tool? How does the Diyanet's influence differ in foreign countries' contexts? What factors determine the Diyanet's scopes in different foreign countries?

\section{INDEX}

Keywords: Diyanet, Islam, secularism, Turkey, religious institution

\section{AUTHOR}

\section{AHMET ERDI ÖZTÜRK}

Swedish Institute Fellow at Linköping University's REMESO and Visiting Scholar at University of Notre Dame's Kroc Institute 